In the UK and rest or world (except North America)

- Online at www.royalinstitutephilosophy.org/think

- Send a cheque payable to The Philosophers'Magazine to Think (Subscriptions Dept), PO Box 464, Berkhamstead, Herts HP4 2UR

- Phone (01442) 879097

- Fax (01442) 872279

Rates (Annual subscription, 3 issues)

UK: $\quad £ 15$ (individuals) $£ 40$ (institutions)

Europe: $\quad £ 18$ (individuals) $£ 40$ (institutions)

ROW: $\quad £ 24$ (individuals) $£ 44$ (institutions)

\title{
North America
}

- Online at www.royalinstitutephilosophy.org/think

- Send a cheque payable to The Philosophers'Magazine to Think, c/o The Philosophy Documentation Center, P.O.

Box 7171 Charlottesville, VA 22906-7171, USA

- Phone 1-800-444-2419

- Fax (419) 3726987

Rates (Annual subscription, 3 issues)

$\$ 24.95$ (individuals) $\$ 60$ (institutions)

Guidelines for contributors (cont. from inside front cover) House style

The editor would be grateful if final submissions were in the Think house style. Please use single quotation marks (double when embedded) and dashes - like this - rather than hyphens - like this - for punctuation. Please italicize rather than underline.

Where it is unavoidable that notes be included, they should be endnotes in the Think style. Examples:

Fred Author, Title of The Book (Place: Publisher, 2002), p. 23.

D. Academic, 'Title of Paper', A Journal, vol.1, no.1 (1990), pp. 3456. 


\section{Think}

issue eleven • autumn 2005

Think is the Royal Institute of Philosophy's periodical of philosophy for everyone, published three times a year.

Included in this issue:

Michael Ruse Intelligent design theory

and its context

Phillip E Johnson Intelligent design in biology Michael Behe Evidence for intelligent design from biochemistry

H Allen Orr Darwin v. intelligent design (again)

Hugh Mellor Accepting the universe

Sharon Kaye and Robert Prisco In the

end it's the tail: Aquinas's fifth proof

Antony Flew My 'conversion'

Dene Bebbington The wrong way to

infer design

Richard D Ryder The case against hunting Thomas Riggins Michael Levin on gay sex David Robjant Levin on the abnormality of homosexuality

Mikel Burley Biology and anti-homosexual disgust

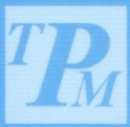

ISSN 1477-1756

Philosophy

ISSN: 1477-1756

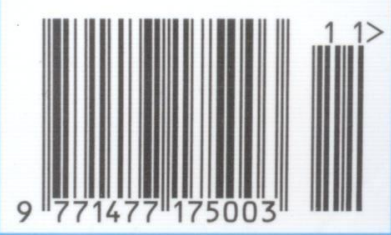

Recommended Price

UK $£ 5.99$ 